Article

\title{
Importance of Detailed Soil Information for Hydrological Modelling in an Urbanized Environment
}

\author{
Johan van Tol ${ }^{1, * \mathbb{C}}$, George van Zijl ${ }^{2}$ and Stefan Julich ${ }^{3}$ (I) \\ 1 Department of Soil, Crop and Climate Sciences, University of the Free State, Bloemfontein 9300, South Africa \\ 2 Unit for Environmental Sciences and Management, North-West University, Potchefstroom 2520, \\ South Africa; george.vanzij1@nwu.ac.za \\ 3 Institute of Soil Science and Site Ecology, Technische Universität Dresden, Pienner Str. 19, \\ 01737 Tharandt, Germany; stefan.julich@tu-dresden.de \\ * Correspondence: vantoljj@ufs.ac.za; Tel.: +27-51-401-2386
}

Received: 6 May 2020; Accepted: 3 June 2020; Published: 13 June 2020

\begin{abstract}
Soil information is critical in watershed-scale hydrological modelling; however, it is still debated which level of complexity the soil data should contain. In the present study, we have compared the effect of two levels of soil data on the hydrologic simulation of a mesoscale, urbanised watershed $\left(630 \mathrm{~km}^{2}\right)$ in central South Africa. The first level of soil data, land type $(\boldsymbol{L T})$ data, is currently the best, readily available soil information that covers the whole of South Africa. In the $\mathbf{L T}$ database, the entire study area is covered by only two soil types. The second level of soil data (DSM) was created by means of digital soil mapping based on hydropedological principles. It resulted in six different soil types with different hydrological behaviour (e.g., interflow, recharge, responsive). The two levels of soil data were each included in the revised version of the Soil and Water Assessment Tool (SWAT+). To compare the effects of different complexity of soil information on the simulated water balance, the outputs of the uncalibrated models were compared to the three nested gauging stations of the watershed. For the $\boldsymbol{L T}$ scenario, the simulation efficiencies calculated with the Kling-Gupta efficiency (KGE) for the three nested gauging stations $\left(640 \mathrm{~km}^{2}, 550 \mathrm{~km}^{2}, 54 \mathrm{~km}^{2}\right)$ of $0,0.33$ and -0.23 were achieved, respectively. Under the DSM scenario, KGE increased to $0.28,0.44$ and 0.43 indicating an immediate improvement of the simulation by integrating soil data with detailed information on hydrological behaviour. In the $\boldsymbol{L} T$ scenario, actual evapotranspiration (aET) was clearly underestimated compared to MODIS-derived aET, while surface runoff was overestimated. The $\boldsymbol{D S M}$ scenario resulted in higher simulated aET compared to $\boldsymbol{L T}$ and lower surface runoff. The higher simulation efficiency of DSM in the smaller headwater catchments can be attributed to the inclusion of the interflow soil type, which covers the governing runoff generation process better than the $\boldsymbol{L T}$ scenario. Our results indicate that simulations benefit from more detailed soil information, especially in smaller areas where fewer runoff generation processes dominate.
\end{abstract}

Keywords: hydrological processes; hydropedology; predictions in ungauged basins; SWAT+ model

\section{Introduction}

Soil is a dominant factor in controlling hydrological flowpaths through partitioning precipitation into different components of the water balance. This is due to the ability of soil to store and transmit water [1]. Soil information is therefore an important input into physically based hydrological models [2,3], but soil information is often not readily available in appropriate format for modellers to use [4]. Reasons for this are, firstly, that existing soil maps were not primarily produced with hydrological modelling purposes in mind [5], and, secondly, the costs and time involved in measuring important soil hydraulic properties 
(e.g., water retention characteristics and conductivity) and representing these properties spatially. The result is that the level of spatial detail of soil inputs is seldom comparable with other spatial inputs, such as remote-sensed land use and topography. Consequently, the models rely strongly on calibration against measured data, to optimise simulations and account for the lack of adequate representation of the heterogeneous landscape [6-8]. These models tend to be over-parameterised, with many combinations of the model structure or parameters leading to the same final result (i.e., equifinality $[9,10])$. This leads to uncertainty about whether the models are representing the hydrological processes dominating in a particular area. Often these models then 'work' in the specific area where they were calibrated, but for the wrong process reasons [11]. This limits their value to predicting the impact of climate and land-use change, as well as their extrapolation value to 'ungauged' areas.

The advances in digital soil mapping (DSM; [12]) have paved the way for providing detailed soil information in an adequate scale and format for hydrological modelling studies (e.g., [7,13-17]). But does this enhanced soil information translate into more efficient modelling? Several studies found that there is improved accuracy in modelling results when compared to measured streamflow or at least reduced parameter uncertainty during calibration [14,16,18-20]. For example, the inclusion of more detailed soil descriptions and representation in the Agriculture Catchments Research Unit (ACRU) model led to an increase in Nash-Sutcliffe efficiency (NSE) of between $9 \%$ and $52 \%$ in semi-arid catchments in South Africa [14]. DSM using the Soil Land Inference Model (SoLIM) yielded a more detailed soil map for a data-scarce area in Portugal [16]. When this map was used to parameterise the Soil and Water Assessment Tool (SWAT) model, it resulted in an increase in NSE of around 7\% compared to legacy soil data. Romanowicz et al. [18], evaluated the contribution of 'generic' (1:500,000 scale) and 'detailed' (1:25,000 scale) soil maps to streamflow prediction accuracies. Using several model setups in SWAT, the detailed soil information outperformed the course soil information in predicting streamflow accurately. The sensitivity of the SWAT model to soil information, and contribution of detailed soil distribution to streamflow predictions, was further demonstrated in the improved simulation efficiency when detailed Soil and Terrain (SOTER) data was used instead of coarse SOTER data, in Benin [19]. Others maintain that the small improvements in modelling accuracy do not necessarily justify the cost and time to gather improved soil information [21]. In general, these studies agree that the physical-based distributed models on which the different levels of soil information were tested are very sensitive to the soil data. Most of these studies also relied on calibration of the models, and they focus therefore on the optimisation of the model using different levels of soil information.

In this study, the objective was to evaluate the impact of different levels of soil information on model performance. The hypothesis was that improved soil information, developed through DSM, will reflect hydrological processes more accurately, and this will translate into improved simulation efficiency. The focus was on the direct contribution of improved soil information to modelling efficiency and we did not try to optimize the model through extensive calibration, essentially treating the catchment as ungauged. We further explored the changes in simulated processes resulting from the different soil information sets and the impact thereof on water resource management.

\section{Materials and Methods}

\subsection{Study Area}

The study area is approximately $630 \mathrm{~km}^{2}$ and lies between Johannesburg (largest city in South Africa) and the capital city, Pretoria (Figure 1). The area lies in the Gauteng Province, which hosts a quarter of the country's population (59 million) and is responsible for generating the majority of the gross domestic product. Due to the economic importance of the area, it is subjected to significant development pressure resulting from urbanisation. 


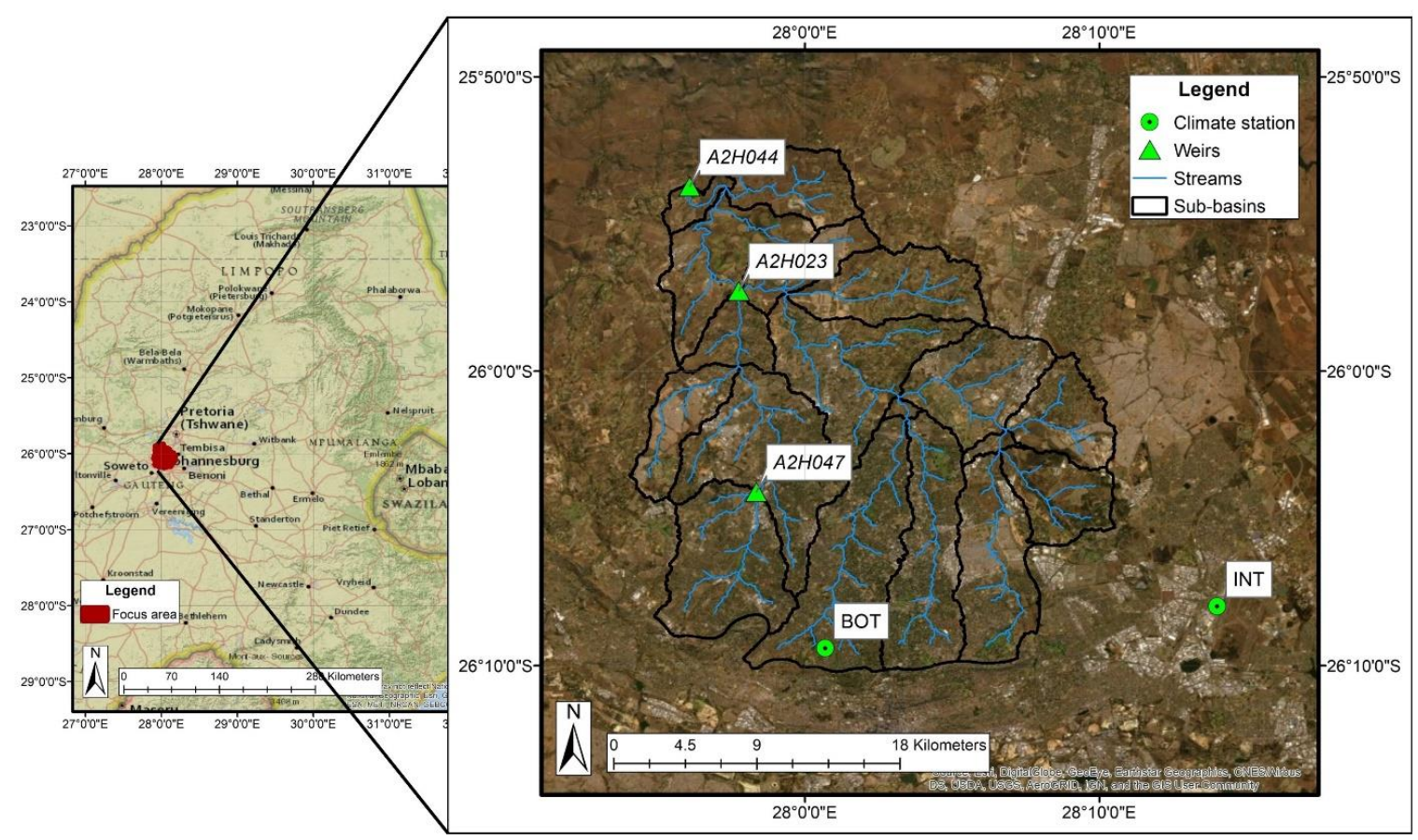

Figure 1. The study area with sub-basins, weirs and climate stations. The City of Johannesburg is located in the south with the capital city of South Africa, Pretoria, in the north.

The Jukskei River drains the catchment in a northerly direction. The geology of the study site is granite and gneiss of the Lanseria Gneiss of the Johannesburg Dome Granite [20,22] with Leptosols, Plinthosols, Cambisols, Stagnosols and Fluvisols being the dominant reference groups found [23]. The vegetation type is Egoli Granite Grassland, forming part of the Mesic Highveld Grassland Bioregion [24]. More than two-thirds of this vegetation unit has been transformed by urbanisation. The catchment lies between 1245 and 1709 m.a.s.l., on the Highveld of South Africa. The terrain is hilly, with the majority of hillslopes having an average slope of less than $5 \%$. The climate is marked by convectional thunderstorms during summer months (October to April), with an average annual rainfall of around $700 \mathrm{~mm}$. Days are hot during summer (average maximum temperature of around $25^{\circ} \mathrm{C}$ ) with cold nights during winter (average minimum temperature of approximately $4{ }^{\circ} \mathrm{C}$ ).

\subsection{The SWAT+ Model, Model Inputs and Setup}

The hydrological model SWAT+ (v 1.2.3) was used for the modelling with QSWAT+ (v. 1.2.2) to set up the watershed. SWAT+ is a revised version of the well-known Soil and Water Assessment Tool (SWAT; [25]). SWAT is a process-based semi-distributed catchment scale model which is widely used to simulate water quality and quantity to predict and assess the impacts of land use, climate change, soil erosion and pollution. As one of the first steps, the model divides the catchment into hydrological response units (HRUs). An HRU is a homogenous area in terms of soils, land use and slope. The model calculates various components of the water balance, such as overland flow, infiltration, lateral flow, percolation, evapotranspiration and discharge to the stream from each HRU. In addition, the model is capable of simulating crop growth and nutrient/pollution fluxes through the landscape. For a more complete description of the SWAT model see [26], and for changes in the SWAT+ version see [27]. Only a few important inputs and processes in the model are discussed here. The model was run from January 2000 until December 2013. The first three years were used as a warm-up period, followed by 11 years of validation. Since the aim of the study was to evaluate the direct contribution of improved soil information to modelling efficiency, we did not include a calibration period. 


\subsubsection{Topography and Land Use}

Elevation was obtained from a 30-m Shuttle Radar Topography Mission Digital Elevation Model (SRTM DEM) ([28]; Figure 2a). The current land use was obtained from the 2013-2014 SA National Land-Cover Map dataset [29]. The land-cover was re-grouped into SWAT land uses with pre-defined parameters for each use (Figure $2 b$ ).

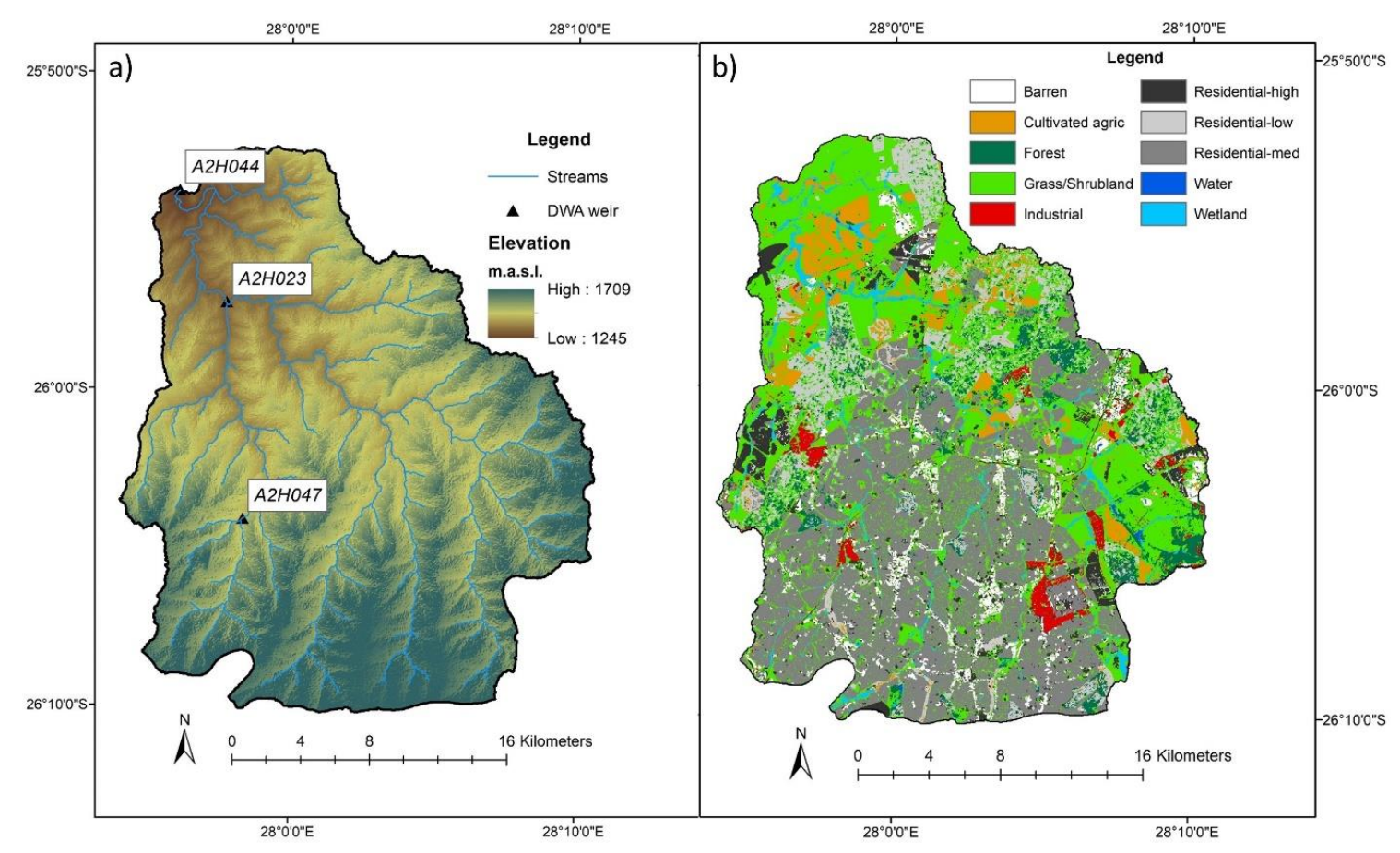

Figure 2. (a) Elevation of the study catchment with streams and Department of Water Affairs (DWA) weirs; (b) dominant land-use in the study area as modified from the National Land Cover Map 2013-2014 [29].

\subsubsection{Climate Information}

Daily rainfall and minimum and maximum temperatures were obtained from two climate stations, namely, the Johannesburg Botanical Gardens (BOT) and OR Tambo Airport (INT) (Figure 1) of the South African Weather Service. Daily solar radiation, relative humidity and wind speed were obtained from the Climate Forecast System Reanalysis (CFSR) project [30], done by the National Center for Environmental Prediction (NCEP). This information was used to calculate daily potential evapotranspiration using the Penman-Monteith approach.

\subsubsection{Soil Information}

SWAT+ requires a soil dataset as a spatial layer. Details on soil horizons such as depth, particle size distribution, saturated hydraulic conductivity $\left(\mathrm{K}_{\mathrm{s}}\right)$, bulk density $\left(\mathrm{D}_{\mathrm{b}}\right)$, carbon content and available water capacity $(\mathrm{AWC})$ are required for each layer. The latter is synonymous with the more familiar 'plant available water'.

Two levels of soil information were used in this study (Figure 3). The first was the land type ( $L T$ ) database [31]. The $\boldsymbol{L T}$ database is the only soil dataset that covers the whole of South Africa at a 1:250,000 scale. A land type is an area with relatively homogenous soil forming factors (climate, geology and topography) resulting in relatively homogenous soil distribution patterns [32]. The $\boldsymbol{L T}$ database is currently the best readily available source of hydrological soil information available in South Africa. With the exception of $K_{\mathrm{s}}$, all the SWAT+ required properties for the $\boldsymbol{L T}$ data are available 
from [33] and are summarized in Table 1. ROSSETTA [34] was used to derive the $\mathrm{K}_{\mathrm{s}}$ for different horizons from the texture classes.

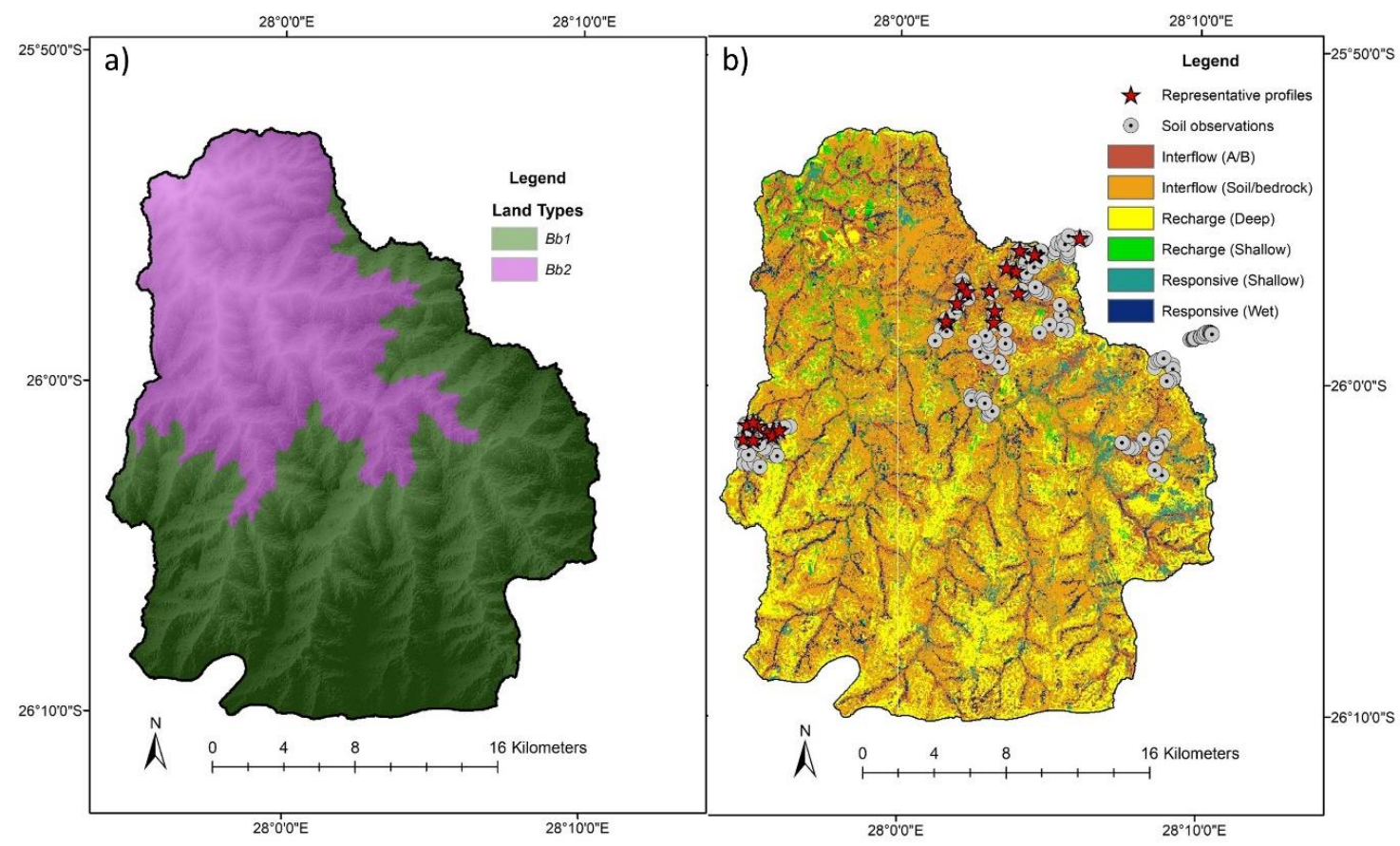

Figure 3. Different levels of soil information used in the study: (a) land type information ( $L T$ ) obtained from the [31] and (b) Digital Soil Map (DSM) data, produced by [17,35], together with locations of representative profiles used to derive hydraulic properties of the soil types.

Table 1. Selected hydraulic properties of the soil horizons in different soil information datasets.

\begin{tabular}{|c|c|c|c|c|c|c|c|c|c|c|c|}
\hline \multirow{2}{*}{ Level } & \multirow{2}{*}{ Soil Group } & \multirow{2}{*}{ Hydro-Group } & \multirow[t]{2}{*}{ Horizon } & \multirow{2}{*}{$\begin{array}{c}\text { Depth } \\
\mathrm{mm}\end{array}$} & \multirow{2}{*}{$\frac{\mathrm{Db}^{1}}{\text { g.cm }}$} & AWC $^{2}$ & $\mathrm{Ks}^{3}$ & $\mathrm{OC}^{4}$ & Clay & Silt & Sand \\
\hline & & & & & & \multicolumn{2}{|c|}{$\mathrm{mm} \cdot \mathrm{mm}^{-1} \mathrm{~mm} \cdot \mathrm{h}^{-1}$} & \multicolumn{4}{|c|}{$\%$} \\
\hline \multirow{4}{*}{ Land Type (LT) } & \multirow{2}{*}{$\mathrm{Bb} 1$} & \multirow{2}{*}{ B } & A & 300 & 1.4 & 0.09 & 16.2 & 1.5 & 15.0 & 10.0 & 75.0 \\
\hline & & & B & 660 & 1.5 & 0.09 & 6.9 & 0.5 & 20.0 & 10.0 & 70.0 \\
\hline & \multirow{2}{*}{$\mathrm{Bb} 2$} & \multirow{2}{*}{ B } & A & 300 & 1.5 & 0.88 & 11.9 & 1.5 & 18.0 & 10.0 & 73.0 \\
\hline & & & B & 790 & 1.6 & 0.68 & 7.3 & 0.5 & 23.0 & 10.0 & 69.0 \\
\hline \multirow{16}{*}{$\begin{array}{c}\text { Digital soil } \\
\text { mapping(DSM) }\end{array}$} & \multirow{3}{*}{ Recharge (deep) } & \multirow{3}{*}{ A } & A & 300 & 1.4 & 0.09 & 218.5 & 1.2 & 21.6 & 11.1 & 67.6 \\
\hline & & & $\mathrm{B}$ & 1200 & 1.3 & 0.09 & 172.0 & 0.8 & 29.7 & 13.2 & 57.2 \\
\hline & & & $\mathrm{C}$ & 1500 & 1.4 & 0.08 & 56.9 & 0.4 & 27.1 & 15.7 & 57.6 \\
\hline & $\begin{array}{l}\text { Recharge } \\
\text { (shallow) }\end{array}$ & $\mathrm{A}$ & A & 300 & 1.4 & 0.12 & 218.5 & 1.6 & 21.6 & 11.1 & 67.6 \\
\hline & \multirow{3}{*}{ Interflow $(\mathrm{A} / \mathrm{B})$} & \multirow{3}{*}{$\mathrm{C}$} & $\mathrm{A}$ & 300 & 1.4 & 0.06 & 112.5 & 1.8 & 21.6 & 11.1 & 67.6 \\
\hline & & & $\mathrm{E}$ & 600 & 1.3 & 0.09 & 87.5 & 0.6 & 29.1 & 14.7 & 56.6 \\
\hline & & & B & 1200 & 1.4 & 0.08 & 2.0 & 0.5 & 46.2 & 14.2 & 39.7 \\
\hline & \multirow{4}{*}{$\begin{array}{c}\text { Interflow } \\
\text { (soil/bedrock) }\end{array}$} & \multirow{4}{*}{ B } & A & 300 & 1.4 & 0.13 & 218.5 & 1.8 & 21.6 & 11.1 & 67.6 \\
\hline & & & B & 800 & 1.3 & 0.07 & 172.0 & 0.8 & 29.1 & 14.7 & 56.6 \\
\hline & & & $\mathrm{C}$ & 1000 & 1.5 & 0.06 & 15.0 & 0.4 & 46.2 & 14.2 & 39.7 \\
\hline & & & $\mathrm{R}$ & 1500 & 1.8 & 0.06 & 0.1 & 0.0 & 46.2 & 14.2 & 39.7 \\
\hline & \multirow{3}{*}{ Responsive (wet) } & \multirow{3}{*}{$\mathrm{D}$} & A & 300 & 1.4 & 0.06 & 10.2 & 2.1 & 21.6 & 11.1 & 67.6 \\
\hline & & & G & 1000 & 1.2 & 0.07 & 5.0 & 0.9 & 52.8 & 19.6 & 27.6 \\
\hline & & & G2 & 1300 & 1.6 & 0.06 & 0.1 & 0.4 & 52.8 & 19.6 & 27.6 \\
\hline & \multirow{2}{*}{$\begin{array}{l}\text { Responsive } \\
\text { (shallow) }\end{array}$} & \multirow{2}{*}{$\mathrm{C}$} & A & 300 & 1.4 & 0.13 & 10.2 & 1.8 & 21.6 & 11.1 & 67.6 \\
\hline & & & $\mathrm{R}$ & 500 & 1.8 & 0.07 & 1.0 & 0.0 & 46.2 & 14.2 & 39.7 \\
\hline
\end{tabular}

${ }^{1}$ Db-bulk density; ${ }^{2}$ AWC-Available Water Capacity; ${ }^{3}$ Ks-saturated hydraulic conductivity; ${ }^{4} \mathrm{OC}$-organic carbon.

The second soil data set was developed through a digital soil mapping approach and is called $D S M$ data for the remainder of this paper. The development of the soil map used in this study is 
discussed in detail in $[17,35]$. Here, we provide only key methodological steps that were followed to create the DSM dataset:

- Environmental covariates (e.g., elevation, slope, topographic wetness index and NDVI) were obtained for the entire Halfway House Granite area (approximately $1050 \mathrm{~km}^{2}$ ).

- $\quad$ The conditioned hypercube sampling method (cHLHS) was used to identify 30 hillslopes which are representative of the entire attribute space. Accessibility of the sites was an important consideration. Landowners are not always keen 1) to allow you on their property and 2) allow digging of profiles on their lawns. Large areas of the catchment are also urbanized (Figure 2b) and the surface sealed; this explains the concentration of observation locations in certain areas (Figure 3b).

- A total of 273 soil observations were made with hand auger (Figure 3b). The soils were classified in accordance with the South African Soil Classification [36] and then regrouped into hydropedological soil types (Table 2; [37]).

- The soil observation database was then divided into training (75\%) and evaluation (25\%) observations. The soil map was then created in $\mathrm{R}$ by running the multinomial logistic regression algorithm (MNLR; [38]) on the training data. The produced map (Figure 3b), had an evaluation point accuracy of $80 \%$ and a Kappa statistic value of 0.71 [17], which indicates a substantial agreement with reality, and was therefore deemed to be acceptable for use in the modelling exercise.

- Hydraulic properties for representative profiles were obtained from two consultancy projects in the area $[39,40]$. Representative profiles $(n=24$; Figure $3 b)$ of different hydropedological types were opened. These profiles were typical 'modal' profiles representing the soil forms (Table 2).

- Undisturbed core samples were collected from diagnostic horizons. The core samples were used to determine $D_{b}$, particle size distribution, and the water retention characteristics using the hanging column method. The double ring infiltration method was used to determine the $\mathrm{K}_{\mathrm{s}}$ of diagnostic soil horizons in situ. For more specific details on the sample strategy and measurement methodology, see [39].

- Lastly, the hydraulic properties used as SWAT+ inputs for the different horizons of the hydropedological soil types were obtained by averaging these property values of the soil forms in the specific hydropedological soil type (Table 2). These values are summarised in Table 1.

Contrasting with the $L T$ database, the DSM map shows higher variety of soils (two vs. six), and there is considerably more detail on the spatial distribution of the soils (Figure 3). The DSM dataset is dominated by the hydropedological classes 'interflow (soil/bedrock)' and 'recharge (deep)'.

\subsubsection{Validation Data and Statistical Comparison}

Streamflow data was recorded at three weirs, managed by Department of Water Affairs (DWA), in the catchment, with long-term measurements (Figure 1). A2H044 drains the entire studied catchment $\left(630 \mathrm{~km}^{2}\right)$, whereas A2H043 and A2H047 drain approximately $550 \mathrm{~km}^{2}$ and $54 \mathrm{~km}^{2}$, respectively. Daily streamflow was converted to monthly average values for comparison purposes.

We also compared simulated actual evapotranspiration (S-aET) against aET derived from energy balance modelling using remote sensing data as input. We used data from MOD16 [41,42], which is also based on the Penman-Monteith approach. The 8-day aET was converted to monthly values and averaged for the entire basin using a 'weighted average' approach. This was done by (1) assigning a monthly aET value for each landscape unit (LSU), (2) multiplying this by the fraction of the basin covered by the specific LSU, and (3) adding the aET for all LSU to get a basin value. The monthly average basin value was compared to monthly S-aET at basin scale. 
Table 2. Hydropedological soil types used in the DSM data, their dominant characteristics and similar WRB, IUSS reference groups.

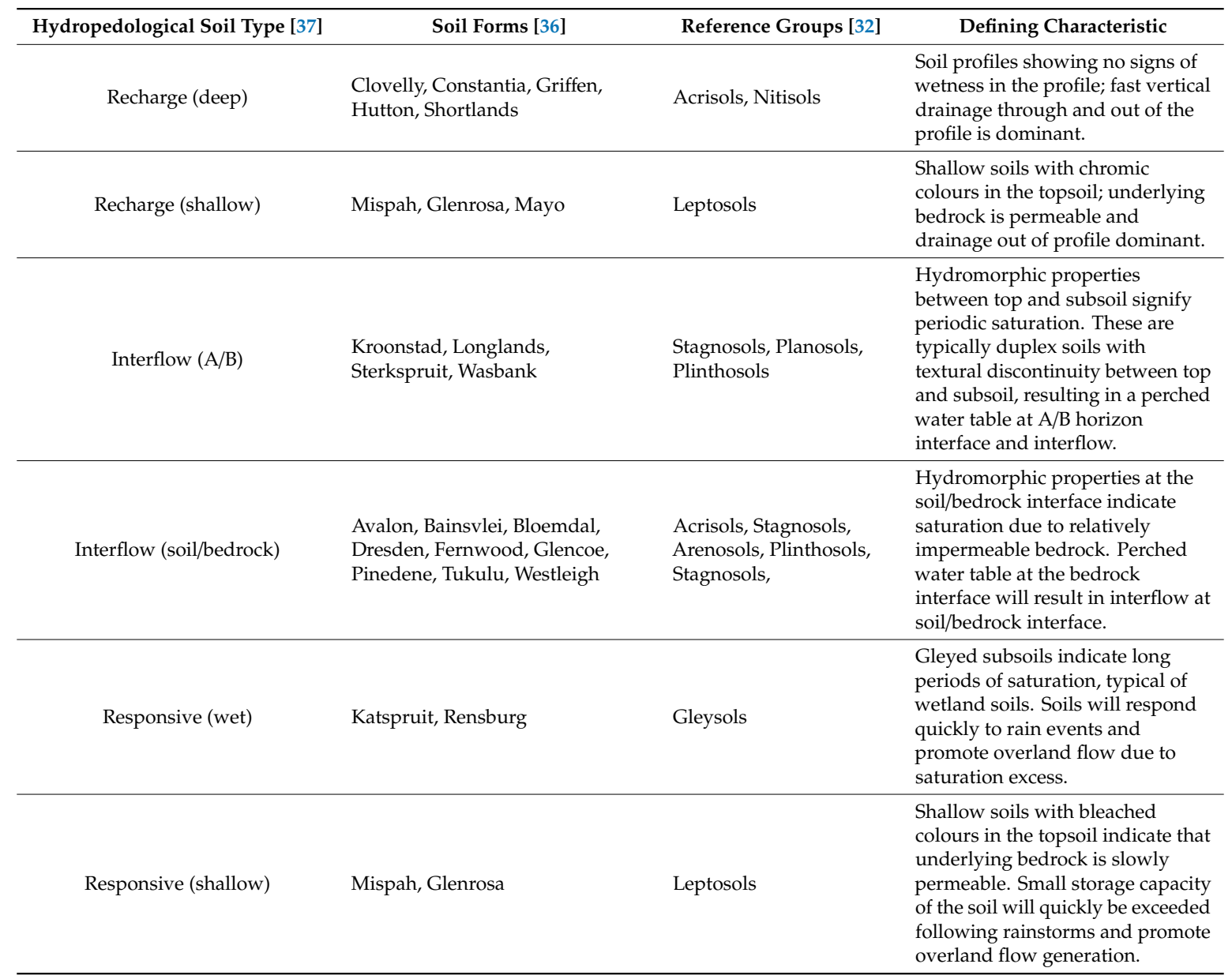

For statistical comparisons, we made use of three widely used statistical indices, namely coefficient of determination $\left(\mathrm{R}^{2}\right)$, root-mean-square error (RMSE) and the Kling-Gupta efficiency (KGE). The latter is calculated using [43]:

$$
K G E=1-\sqrt{(r-1)^{2}+\left(\frac{\sigma_{s i m}}{\sigma_{o b s}}-1\right)^{2}+\left(\frac{\mu_{s i m}}{\mu_{o b s}}-1\right)^{2}}
$$

where $r$ represents the correlation coefficient, $\sigma_{\text {sim }}$ and $\sigma_{\text {sim }}$ the standard deviations in simulations and observations, respectively, and $\mu_{\text {sim }}$ and $\mu_{\text {obs }}$ the means of simulations and observations. KGE $=1$ represents a perfect fit and values smaller than -0.41 imply that the means of the observations provide a better fit than the model [44]. In addition to these statistical indices, we assessed streamflow time series, yearly water balances and spatial aET visually to aid in the discussion of model output.

\section{Results}

The two model set-ups had identical numbers of sub-basins (19) and landscape units (230), because the same DEM was used to delineate these. The number of HRUs was, however, twice as high for the $\boldsymbol{D S M}$ simulation when compared to the $\boldsymbol{L} \boldsymbol{T}$ simulation (i.e., 2034 and 1132, respectively). This is due to the higher level of detail in the DSM soil map compared to the $\mathbf{L T}$ soil map (Figure 3).

For both $L T$ and $D S M$ simulations, baseflow was substantially underestimated in the two larger catchments (Figure 4). The underestimation is more pronounced in the larger $\left(>500 \mathrm{~km}^{2}\right)$ catchment (Figure $4 \mathrm{a}, \mathrm{b}$ ) than in the smaller $\left(54 \mathrm{~km}^{2}\right)$ catchment (Figure $4 \mathrm{c}$ ). Overestimation of peak flows is 
associated with both model runs, but more obvious with $L T$ simulations than DSM simulations. Statistical indices indicate that there are moderate correlations with observed streamflow $\left(R^{2} \geq 0.6\right)$ at all scales for both simulations. The RMSE error, however, is high and the KGE relatively low. At all three scales, the $\boldsymbol{D S M}$ simulation performed better than the $\boldsymbol{L} \boldsymbol{T}$ simulation when all three statistical indices were considered. The difference in the KGE was especially worth noting in the smaller catchment (Figure 4c) with 0.43 for the $\mathbf{D S M}$ simulation and -0.23 for the $\boldsymbol{L T}$ simulation.

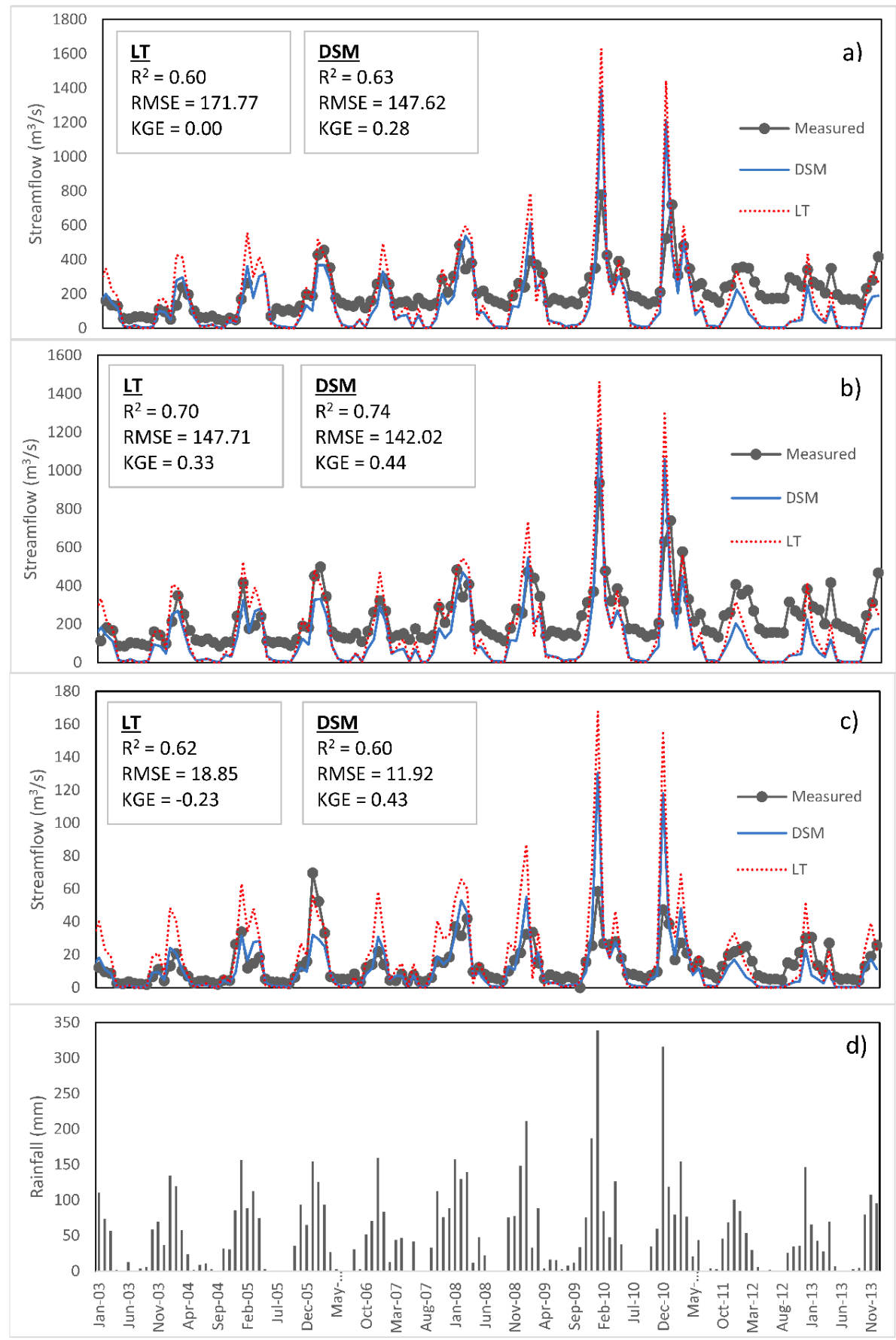

Figure 4. Simulated streamflow for the $\boldsymbol{L T}$ and $D S M$ model runs compared to observed streamflow at the (a) A2H044, (b) A2H023 and (c) A2H047 weirs, respectively, together with (d) the rainfall during the validation. 
When compared to MOD16-derived actual evaporation (aET), both simulations underestimated aET considerably (see deviation from 1:1 line in Figure 5). The underestimation was larger with the $\boldsymbol{L T}$ soil dataset (Figure 5a) than with the DSM dataset (Figure 5b). These differences are also indicated in the RMSE values of 4.6 and 3.4 for the $\boldsymbol{L T}$ and $D S M$ simulations, respectively. The KGE values were also notably lower with the $\mathbf{L T}$ simulation (0.25) when compared to the DSM (0.4) simulation.

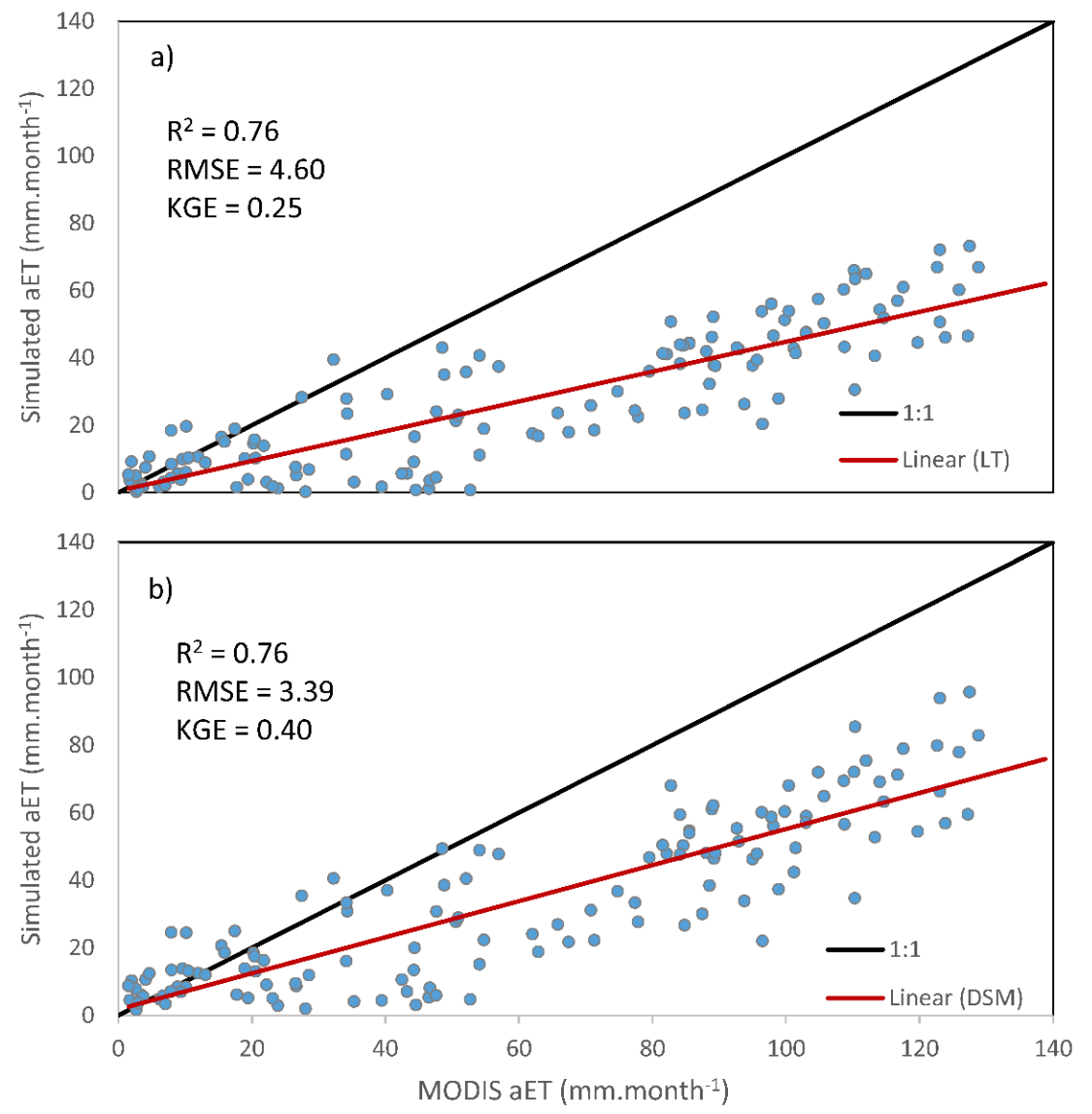

Figure 5. Monthly aET derived from MOD16 against simulated aET using (a) the $\boldsymbol{L T}$ soil dataset and (b) the DSM dataset for the entire basin.

The underestimation of S-aET and streamflow is also visible when yearly average water balance components are considered (Table 3). Total streamflow is underestimated by $17 \%$ for $\mathbf{L T}$ and $38 \%$ for DSM simulations for the entire basin (A2H044). This underestimation was more pronounced at weir A2H023, with 18\% for $\mathbf{L T}$ and $41 \%$ for DSM. In the smaller catchment (A2H047), streamflow was overestimated by $30 \%$ with the $\boldsymbol{L T}$ simulation and underestimated by $18 \%$ under the $\boldsymbol{D S M}$ simulation.

Table 3. Average yearly major water balance components for different simulations for the three studied catchments.

\begin{tabular}{|c|c|c|c|c|c|c|c|c|c|}
\hline \multirow{2}{*}{$\begin{array}{c}\text { Weir } \\
\text { Annual Average Values (mm) }\end{array}$} & \multicolumn{3}{|c|}{ A2H044 $\left(630 \mathrm{~km}^{2}\right)$} & \multicolumn{3}{|c|}{ A2H023 $\left(547 \mathrm{~km}^{2}\right)$} & \multicolumn{3}{|c|}{ A2H047 $\left(54 \mathrm{~km}^{2}\right)$} \\
\hline & Observed & $D S M$ & $L T$ & Observed & DSM & $L T$ & Observed & $D S M$ & $L T$ \\
\hline Precipitation & 635 & 635 & 635 & & 638 & 638 & & 616 & 616 \\
\hline Total discharge & 350 & 216 & 292 & 367 & 218 & 302 & 262 & 214 & 341 \\
\hline Overland flow & & 59 & 255 & & 61 & 265 & & 72 & 318 \\
\hline Lateral flow & & 156 & 37 & & 156 & 37 & & 142 & 23 \\
\hline Percolation & & 10 & 16 & & 10 & 15 & & 10 & 11 \\
\hline aET & $723^{1}$ & 407 & 326 & & 409 & 319 & & 391 & 263 \\
\hline pET & & 1796 & 1796 & & 1796 & 1796 & & 1800 & 1800 \\
\hline
\end{tabular}

${ }^{1}$ MOD16-derived aET for observed. 
For the $\boldsymbol{L T}$ simulation, streamflow to rainfall is approximately $46 \%$, with $51 \%$ of the rainfall contributing to evapotranspiration in the entire catchment (A2H044). The streamflow:rainfall ratio is considerably smaller for the DSM simulation (34\%), with a larger contribution to evaporation (64\%) for this catchment. The total discharge for the $\mathbf{L T}$ simulation is considerably higher when compared to the DSM simulation at all scales, a difference of 76, 84 and 127 mm.year ${ }^{-1}$ for A2H044, A2H023 and A2H047, respectively. This increase is largely due to a 4-fold increase in the simulated overland flow under $\mathbf{L T}$ at all scales. The lateral flow component of the DSM simulation is, however, between four and six times higher than for the $\mathbf{L T}$ simulation.

Yearly average MOD16-derived aET is $723 \mathrm{~mm}$, which is considerably higher than the rainfall. S-aET is approximately half of the MOD16-derived aET. Differences between S-aET of the different model runs are worth noting. At all scales, $\boldsymbol{L T}$ produced less S-aET than DSM; these differences amount to $24 \%, 28 \%$ and $48 \%$ with decreasing catchment size (Table 3 ).

The variation in lateral flow simulation is remarkable (Figure 6). The majority of LSUs in the $\mathbf{L T}$ simulation produced less than $30 \mathrm{~mm}_{\text {.year }}{ }^{-1}$ (Figure 6a), whereas almost all of the LSUs in the DSM simulation produced more than $90 \mathrm{~mm}$ year $^{-1}$ (Figure 6b). It is also worth noting that there is limited visual correlation between the relatively low- and high-producing LSUs of the LT simulation and the relatively low- and high-producing LSUs of the DSM simulations.

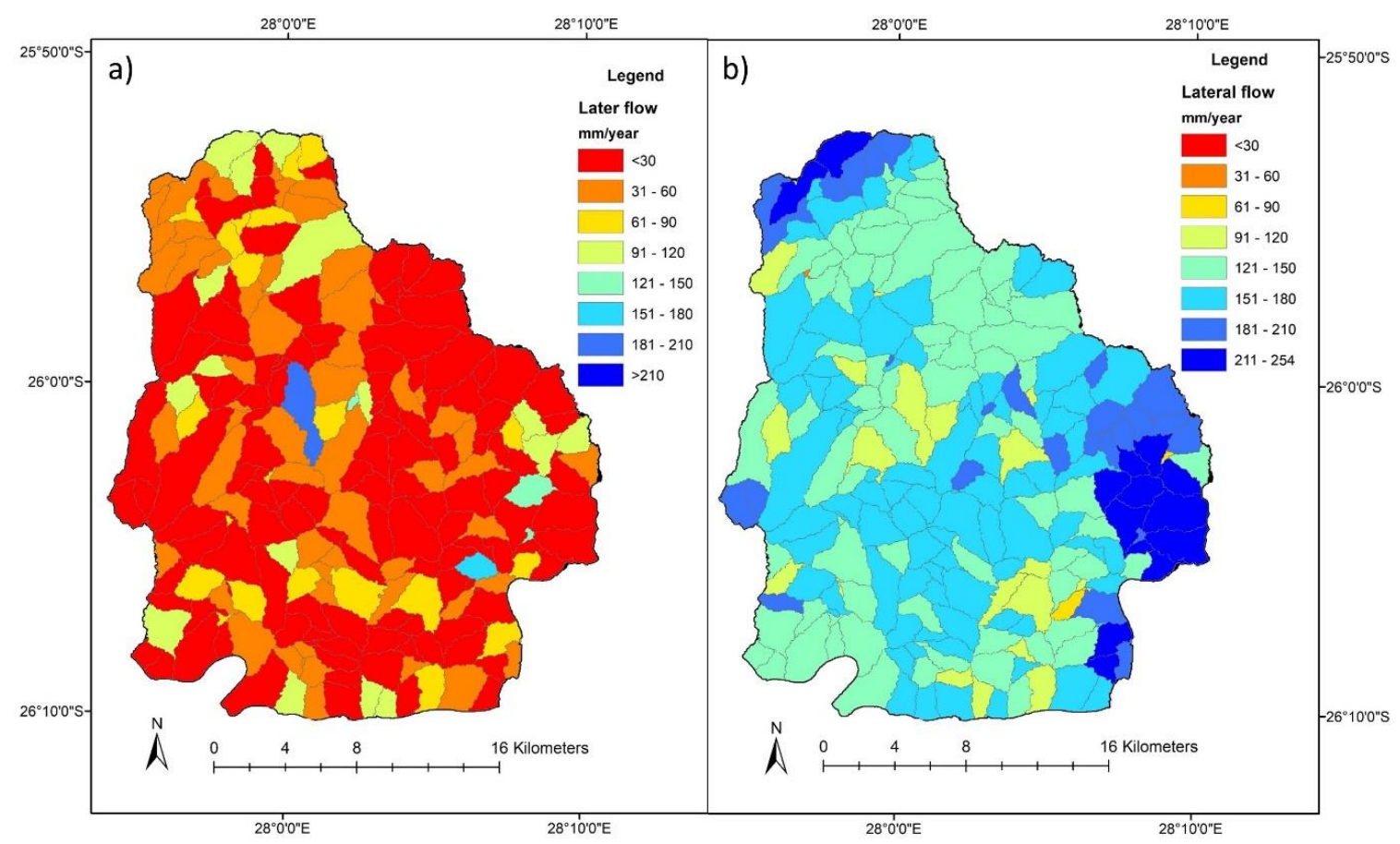

Figure 6. Simulated lateral flow (mm.year ${ }^{-1}$ ) at landscape unit scale for the (a) $L T$ and (b) DSM simulations.

\section{Discussion}

\subsection{Streamflow Simulations}

The streamflow predictions were surprisingly accurate (especially for weir A2H023), considering that the models were not calibrated against measured flow. Similar studies, for example, obtained $\mathrm{R}^{2}$ values of between 0.42 and 0.71 [19], 0.15 [20], and between 0.61 and 0.74 [21]. In terms of quantifying overall modelling efficiency, the KGE captures correlation and deviation between simulated and measured values. According to Knoben et al. [44], a KGE of greater than -0.41 implies that the model prediction is a better fit than the mean observed value. With this as benchmark, all the simulations produced 'reasonable' simulations. 
There is, however, a clear underestimation of baseflow in the larger catchments (A2H044 and A2H023), which translates into an underestimation of total streamflow (Figure 4, Table 3). This underestimation could be corrected by adjusting groundwater parameters in the model. Decreasing the threshold depth for return flow to occur (GWQMN), decreasing the coefficient of re-evaporation from the groundwater (GW_REVAP) and increasing the threshold depth of the groundwater before re-evaporation occurs (REVAMPM) for different HRUs will likely increase baseflow contributions [45]. To optimise simulations and evaluate parameter uncertainty could be the objective of a future study (similar to [16]), but, here, we focused on the direct contribution of different soil inputs to the model performance.

From the simulations, it is clear that more detailed soil information provided better simulations, presumably because the governing runoff generation processes are better reflected. The higher $R^{2}$ in the large catchments (Figure 4a,b), especially the higher KGE, indicates better modelling performance. Worth noting is that the improved statistical indices associated with the DSM dataset were observed despite greater underestimation of total discharge on the water balance of the larger catchments (Table 3). This is important, implying that a better representation of the overall water balance does not necessary translate to improved representation of streamflow generation processes. The improved performance can mostly be attributed to improved predictions of peak flows. Higher conductivity $\left(\mathrm{K}_{\mathrm{s}}\right)$ of surface horizons and deeper soils (Table 1) of the DSM soil inputs will increase infiltration and water storage. Moreover, the textural discontinuity of the interflow soils leads to higher simulated subsurface lateral flows (Figure 3), which also has an effect on the simulated peak flows. The relatively low conductivity and comparatively shallower soils (Table 1) of the $\boldsymbol{L} \boldsymbol{T}$ soil inputs will promote overland flow generation and a quick response to rainfall. This is supported by the summary of water balance in Table 3, where $\boldsymbol{L T}$ simulations generated four times more overland flow than DSM simulations.

The impact of more detailed soil information is more pronounced in the smaller catchment (Figure 4c, Table 3), with a marked decrease in RMSE and an increase in the KGE from the $\boldsymbol{L T}$ to $\boldsymbol{D S M}$ simulations. The increase in KGE is especially noteworthy. This statistical index improves from -0.23 to 0.43 . For the $54-\mathrm{km}^{2}$ catchment, the more detailed soil information improved the model predictions from relatively 'poor' to 'acceptable'. In the $54-\mathrm{km}^{2}$ catchment, the improvement in the simulations is also visible in the water balance. Total discharge is underestimated by $18 \%$ for the DSM simulation (compared to $>38 \%$ for the same soil dataset in the lager catchments), whereas the $\boldsymbol{L T}$ simulations overestimate streamflow by $30 \%$. From our simulations, it appears that detailed soil information becomes more important in smaller areas, where fewer runoff generation processes dominate, a notion supported by [14]. It is also important to recognize that land-use change, such as urbanisation or open-cast mining, is site-specific. Details of where, when and which hydrological processes dominate are therefore vital for planning in smaller catchments. The optimum scale of soil data for different-sized catchments is however still not known, and certainly worth exploring in future.

\subsection{Groundwater Contributions}

The underestimation of baseflow, especially in the larger catchments (Figure 4a,b), could be attributed to groundwater contributions from outside the catchment area. In general, the groundwater level is deeper than $10 \mathrm{~m}$ in the study site [22]. The contribution of groundwater (or fractured rock aquifers) is assumed to be significant, especially during low-rainfall months. Based on our simulations, groundwater contributes to between 62 and $134 \mathrm{~mm}$ of the Jukskei's streamflow per year, i.e., between $18 \%$ and $38 \%$ of streamflow. It would be important to validate these findings through detailed measurements and dedicated modelling.

The external contribution of groundwater from outside the catchment area could also be linked to the underestimation of S-aET when compared to the MOD16 aET (Figure 5, Table 3). One must keep in mind that MOD16 (or other remote-sensed) aET values are also 'modelled' values. Direct comparisons with simulated values and interpretations in relation to hydrological processes should therefore be made with care. In this study, it appears that MOD16 overestimates aET when compared to 
rainfall. This is in contrast with another South African study, where MOD16 underestimated aET when compared to measured values [46]. Regardless, the considerably higher MOD16 aET (compared to S-aET) and the underestimation of baseflow (Figure 4), especially during dry months, suggest that streamflow and aET are supported with contributions of water not accounted for in the catchment water balance.

The relatively smaller underestimation of total discharge in the $54-\mathrm{km}^{2}$ catchment with the DSM simulations and overestimation with the $\boldsymbol{L T}$ simulation could be an indication that groundwater only makes a considerable contribution to higher-order streams.

\subsection{Implications for Management}

In the study area, subsurface lateral flow has important implications for urbanisation. The term 'wet basement syndrome' (WBS, $[39,47]$ ) refers to accumulation of water when lateral flowpaths are intersected by foundations. WBS has implications for infrastructural development (e.g., dampness of walls) and graveyards as well as environmental consequences in the alteration in wetland water regimes. Where wetland waters are supplied through lateral flow, surface sealing or intersection of lateral flowpaths will change the water regimes and, ultimately, the ecosystem services provided by the wetland [48].

Representing the spatial distribution of dominant streamflow generation processes is vital for decision making (e.g., $[9,16,19])$. Here, we showed how different soil information datasets impact the spatial representation of lateral flow generation. In Figure 6, the relative contributions of lateral flow on 230 different landscape units (LSU) are presented and they differ not only in terms of the volume of flow generated but also in terms of the spatial distribution of the relatively high- and low-generating LSUs. For decision making purposes, the spatial representation could be refined to HRU scale (2034 units). Such information can help with the planning of development projects, such as the location of subsurface drains, graveyards and the type of foundation to consider in different areas. Without detailed soil information, the importance of lateral flow in this catchment would have been underestimated, and this highlights the role that spatially distributed models can play in the design and evaluation of water management plans [18].

\section{Conclusions}

This work presented results from hydrological simulations using two levels of soil inputs. More detailed soil information, developed through advanced digital soil mapping techniques, resulted in more accurate simulations of streamflow when compared to measured values. The improved simulation accuracy was obtained without calibration of the model. This is promising for hydrological modelling in ungauged areas, where long-term streamflow monitoring for calibration is absent. The underestimation of baseflow, especially in the larger catchments, and potential contribution of groundwater from beyond the catchment boundary are modelling aspects that need to be considered in future studies.

In our study, the impact of the improved soil information was more pronounced in the smaller catchment than in the larger ones. The ideal level of detail (or scale) of soil information for hydrological modelling of different sized catchments remains an important question. It is, however, clear that the SWAT+ model is sensitive to soil inputs, and we argued that the spatial representation of dominant hydrological processes is captured more accurately with more detailed soil information. Any reasonable effort should therefore be made to improve the soil information to realistically reflect hydrological processes in order to improve land use planning, especially in areas dedicated for urbanisation.

Author Contributions: Conceptualization, J.v.T and S.J.; methodology, J.v.T and G.v.Z.; formal analysis, J.v.T; investigation, J.v.T., G.v.Z. and S.J..; writing—original draft preparation, J.v.T.; writing一review and editing, G.v.Z. and S.J; visualization, J.v.T.; funding acquisition, G.v.Z. and J.v.T. All authors have read and agreed to the published version of the manuscript.

Funding: This research was partially funded by the National Research Foundation (NRF Grant: RDYR-116350). 
Acknowledgments: The authors are grateful to the City of Joburg Municipality, the South African Weather Service and Digital Soils Africa for providing important soil and climate data.

Conflicts of Interest: The authors declare no conflict of interest.

\section{References}

1. Park, S.J.; Mcsweeney, K.; Lowery, B. Identification of the spatial distribution of soils using a process-based terrain characterization. Geoderma 2001, 103, 249-272. [CrossRef]

2. Beven, K. Surface water hydrology—Runoff generation and basin structure. Rev. Geophys. 1983, 21, 721-730. [CrossRef]

3. Worqlul, A.W.; Ayana, E.K.; Yen, H.; Jeong, J.; MacAlister, C.; Taylor, R.; Gerik, T.J.; Steenhuis, T.S. Evaluating hydrologic responses to soil characteristics using SWAT model in a paired-watersheds in the Upper Blue Nile Basin. Catena 2018, 163, 332-341. [CrossRef]

4. Lilly, A.; Boorman, D.; Hollis, J.D. The development of a hydrological classification of UK soils and the inherent scale changes. Nutr. Cycl. Agroecosyst. 1998, 50, 299-302. [CrossRef]

5. Zhu, A.X.; Mackay, D.S. Effects of spatial detail of soil information on watershed modelling. J. Hydrol. 2001, 248, 54-77. [CrossRef]

6. McDonnell, J.J.; Sivapalan, M.; Vaché, K.; Dunn, S.; Grant, G.; Haggerty, R.; Hinz, C.; Hooper, R.; Kirchner, J.; Roderick, M.L.; et al. Moving beyond heterogeneity and process complexity: A new vision for watershed hydrology. Water Resour. Res. 2007, 43, 1-6. [CrossRef]

7. Julich, S.; Breuer, L.; Frede, H.-G. Integrating heterogeneous landscape characteristics into watershed scale modelling. Adv. Geosci. 2012, 31,31-38. [CrossRef]

8. Ayana, E.K.; Dile, Y.T.; Narasimhan, B.; Srinivasan, R. Dividends in flow prediction improvement using high-resolution soil database. J. Hydrol. Reg. Stud. 2019, 21, 159-175. [CrossRef]

9. Beven, K.; Freer, J. Equifinality, data assimilation, and uncertainty estimation in mechanistic modelling of complex environmental systems using the GLUE methodology. J. Hydrol. 2001, 249, 11-29. [CrossRef]

10. Beven, K. A manifesto for the equifinality thesis. J. Hydrol. 2006, 320, 18-36. [CrossRef]

11. Seibert, J.; McDonnell, J.J. On the dialog between experimentalist and modeller in catchment hydrology: Use of soft data for multicriteria model calibration. Water Res. Res. 2002, 38, 1241-1252. [CrossRef]

12. McBratney, A.B.; Mendoça Santos, M.L.; Minasny, B. On digital soil mapping. Geoderma 2003, 117, 3-52. [CrossRef]

13. Thompson, J.A.; Roecker, S.; Gunwald, S.; Owens, P.R. Digital soil mapping: Interactions with and applications for hydropedology. In Hydropedology: Synergistic Integration of Soil Science and Hydrology; Lin, H.S., Ed.; Elsevier: Amsterdam, Netherlands, 2012; pp. 665-709.

14. Van Tol, J.J.; van Zijl, G.M.; Riddell, E.S.; Fundisi, D. Application of hydropedological insights in hydrological modelling of the Stevenson Hamilton Research Supersite, Kruger National Park, South Africa. Water SA 2015, 41, 525-533. [CrossRef]

15. Van Zijl, G.M.; van Tol, J.J.; Riddell, E.S. Digital mapping for hydrological modelling. In Digital Soil Mapping Across Paradigms, Scales and Boundaries; Zhang, G., Brus, D., Liu, F., Song, X., Lagacherie, P., Eds.; Springer: Singapore, 2016; pp. 115-129.

16. Wahren, F.T.; Julich, S.; Nunes, J.P.; Gonzalez-Pelayo, O.; Hawtree, D.; Feger, K.H.; Keizer, J.J. Combining digital soil mapping and hydrological modelling data in a data scarce watershed in north-central Portugal. Geoderma 2016, 264, 350-362. [CrossRef]

17. Van Zijl, G.M.; van Tol, J.J.; Bouwer, D.; Lorentz, S.A.; Le Roux, P.A.L. Combining Historical Remote Sensing, Digital Soil Mapping and Hydrological Modelling to Produce Solutions for Infrastructure Damage in Cosmo City, South Africa. Remote Sens. 2020, 12, 433. [CrossRef]

18. Romanowicz, A.A.; Vancloostera, M.; Rounsevelb, M.; La Junesseb, I. Sensitivity of the SWAT model to the soil and land use data parametrisation: A case study in the Thyle catchment, Belgium. Ecol. Modell. 2005, 187, 27-39. [CrossRef]

19. Bossa, A.Y.; Diekkrüger, B.; Igué, A.M.; Gaiser, T. Analyzing the effects of different soil databases on modelling of hydrological processes and sediment yield in Benin (West Africa). Geoderma 2012, 173, 61-74. [CrossRef]

20. Diek, S.; Temme, A.J.A.M.; Teuling, A.J. The effect of spatial soil variation on the hydrology of a semi-arid Rocky Mountain catchment. Geoderma 2014, 235, 113-126. [CrossRef] 
21. Geza, M.; McCray, J.E. Effects of soil data resolution on SWAT model stream flow and water quality predictions. J. Environ. Manag. 2008, 88, 393-406. [CrossRef]

22. Dippenaar, M.A.; Van Rooy, J.L. Review of engineering, hydrogeological and vadose 540 zone hydrological aspects of the Lanseria Gneiss, Goudplaats-Hout River Gneiss and 541 Nelspruit Suite Granite (South Africa). J. Afr. Earth Sci. 2014, 91, 12-31. [CrossRef]

23. IUSS Working Group WRB. World Reference Base for Soil Resources 2014; Update 2015 International Soil Classification System for Naming Soils and Creating Legends for Soil Maps; World Soil Resources Reports No. 106; FAO: Rome, Italy, 2015.

24. South African National Biodiversity Institute (SANBI). The Vegetation Map of South Africa, Lesotho and Swaziland. Mucina, L., Rutherford, M.C., Powrie, L.W., Eds.; Version. 2012. Available online: http: //bgis.sanbi.org/SpatialDataset/Detail/18 (accessed on 14 September 2019).

25. Arnold, J.G.; Srinivasan, R.; Muttiah, R.S.; Williams, J.R. Large area hydrologic modelling and assessment, part I: Model development. J. Am. Water Resour. Assoc. 1998, 34, 73-89. [CrossRef]

26. Neitsch, S.L.; Williams, J.; Arnold, J.; Kiniry, J. Soil and Water Assessment Tool Theoretical Documentation Version 2009; Texas Water Resources Institute: College Station, TX, USA, 2011.

27. Bieger, K.; Arnold, J.G.; Rathjens, H.; White, M.J.; Bosch, D.D.; Allen, P.M.; Srinivasan, R. Introduction to SWAT+, a completely restructured version of the soil and water assessment tool. J. Am. Water Resour. Assoc. 2017, 53, 115-130. [CrossRef]

28. USGS (United States Geological Survey). Landsat Images. Available online: http://landsat.usgs.gov (accessed on 16 September 2019).

29. Geoterraimage. 2013-2014 South African National Land-Cover Dataset; Report Created for Department of Environmental Sciences; DEA/CARDNO SCPF002: Implementation of Land Use Maps for South Africa; Department of Environmental Affairs: Pretoria, South Africa, 2015.

30. Saha, S.; Moorthi, S.; Pan, H.L.; Wu, X.; Wang, J.; Nadiga, S.; Tripp, P.; Kistler, R.; Woollen, J.; Behringer, D.; et al. The NCEP Climate Forecast System Reanalysis. Bull. Am. Meteorol. Soc. 2015, 91, 1015-1057. [CrossRef]

31. Land Type Survey Staff. Land Types of South Africa: Digital Map (1:250,000 Scale) and Soil Inventory Datasets; ARC-Institute for Soil, Climate and Water: Pretoria, South Africa, 1972-2002.

32. Paterson, D.G.; Turner, D.P.; Wiese, L.D.; Van Zijl, G.; Clarke, C.E.; Van Tol, J.J. Spatial soil information in South Africa: Situational analysis, limitations and challenges. S. Afr. J. Sci. 2015, 111, 1-7. [CrossRef]

33. Schulze, R.E. Soils: Agrohydrological Information Needs, Information Sources and Decision Support. In South African Atlas of Climatology and Agrohydrology; Schulze, R.E., Ed.; WRC Report 1489/1/06, Section 4.1; Water Research Commission: Pretoria, South Africa, 2007.

34. Schaap, M.G.; Leij, F.J.; Van Genuchten, M.T. Rosetta, a computer program for estimating soil hydraulic parameters with hierarchical pedotransfer functions. J. Hydrol. 2001, 251, 163-176. [CrossRef]

35. Van Zijl, G.M.; Van Tol, J.J.; Tinnefeld, M.; Le Roux, P.A.L. A hillslope based digital soil mapping approach, for hydropedological assessments. Geoderma 2019, 354, 113888. [CrossRef]

36. Soil Classification Working Group. Soil Classification: A Taxonomic System for South Africa; Department of Agricultural Development: Pretoria, South Africa, 1991.

37. Van Tol, J.J.; Le Roux, P.A.L. Hydropedological grouping of South African soil forms. S. Afr. J. Plant. Soil. 2019, 36, 233-235. [CrossRef]

38. Kempen, B.; Brus, D.J.; Heuvelink, G.B.M.; Stoorvogel, J.J. Updating the 1: 50,000 Dutch soil map using legacy soil data: A multinomial logistic regression approach. Geoderma 2009, 151, 311-326. [CrossRef]

39. Tinnefeld, M.; Le Roux, P.A.L.; Job, N.; Van Zijl, G.M.; Van Tol, J.J.; Lorentz, S.A. Research Report on the Hydropedology of Part of the Halfway House Granite Dome; Department of Infrastructure and Environment, City of Johannesburg Metropolitan Council: Johannesburg, South Africa; University of the Free State, Institute of Groundwater Studies: Bloemfontein, South Africa, 2017.

40. DSA. Cosmo City Hydropedological Report; Report prepared for Johannesburg Roads Agency (JRA); Digital Soils Africa; DSA: Port Elizabeth, South Africa, 2019.

41. ORNL; DAAC. MODIS and VIIRS Land Products Global Subsetting and Visualization Tool. ORNL DAAC, Oak Ridge, Tennessee, USA. Subset obtained for MOD16A2 Product at 25.9549S,27.9639E, Time Period: 2002-01-01 to 2010-12-27, and Subset Size: $60.5 \times 60.5 \mathrm{~km}$. Available online: https://doi.org/10.3334/ORNLDAAC/1379 (accessed on 2 April 2020). 
42. Running, Q.M. MOD16A2 MODIS/Terra Net Evapotranspiration 8-Day L4 Global 500m SIN Grid V006. NASA EOSDIS Land Processes DAAC. 2017. Available online: https://doi.org/10.5067/MODIS/MOD16A2.00 (accessed on 2 April 2020).

43. Gupta, H.V.; Kling, H.; Yilmaz, K.K.; Martinez, G.F. Decomposition of the mean squared error and NSE performance criteria: Implications for improving hydrological modelling. J. Hydrol. 2009, 377, 80-91. [CrossRef]

44. Knoben, W.J.M.; Freer, J.E.; Woods, R.A. Technical note: Inherent benchmark or not? Comparing Nash-Sutcliffe and Kling-Gupta efficiency scores. Hydrol. Earth Sys. Sci. 2019, 23, 4323-4331. [CrossRef]

45. Abbaspour, K.C.; Rouholahnejad, E.; Vaghefi, S.; Srinivasan, R.; Yang, H.; Kløve, B. A continental-scale hydrology and water quality model for Europe: Calibration and uncertainty of a high-resolution large-scale SWAT model. J. Hydrol 2015, 524, 733-752. [CrossRef]

46. Ramoelo, A.; Majozi, N.; Mathieu, R.; Jovanovic, N.; Nickless, A.; Dzikiti, S. Validation of global evapotranspiration product (MOD16) using flux tower data in the African Savanna, South Africa. Remote Sens. 2014, 6, 7406-7423. [CrossRef]

47. Van der Waals, J.H. Hydropedology Wetland Impact Assessment and Management Report; Proposed Linksfield Development Site; Terrasoil: Gauteng Province, South Africa, 2014.

48. Van Tol, J.J.; Lorentz, S.A.; van Zijl, G.M.; Le Roux, P.A.L. The contribution of hydropedological assessments to the availability and sustainable water, for all (SDG\#6). In Soil and Sustainable Development Goals; Lal, R., Horn, R., Kosaki, T., Eds.; Catena-Schweizerbart: Stuttgart, Germany, 2018; pp. 102-117.

(C) 2020 by the authors. Licensee MDPI, Basel, Switzerland. This article is an open access article distributed under the terms and conditions of the Creative Commons Attribution (CC BY) license (http://creativecommons.org/licenses/by/4.0/). 